\title{
Student Motivation and Perseverance: Do They Explain College Graduation?
}

\author{
Rasha Ashraf \\ Georgia State University \\ rashraf@gsu.edu \\ Jonathan M. Godbey \\ Georgia State University \\ Milind M. Shrikhande \\ Georgia State University \\ Tracy A. Widman \\ Georgia State University
}

\begin{abstract}
We examine whether college students' persistence in finding a suitable major field of study influences the likelihood of graduation. We find that students who make an effort to select a suitable major early in their college careers graduate in a more timely fashion. Although changing majors is associated with delayed graduation, struggling students can improve graduation likelihood by switching to a more suitable major. However, performance improvement after switching is necessary for successful completion of a degree. These results indicate that colleges and universities should allocate resources to supporting students in their search for an appropriate major and empower students by providing course guidance and counseling.
\end{abstract}

Keywords: College Retention, Higher Education, College Graduation Rate

\section{Introduction}

Choosing an appropriate major is critical to successfully completing college and laying a strong foundation for a successful professional career. Some students begin their college career with a clear vision of what they want to do, while others lack motivation and enroll in college because of pressure from their family or community to do so. Without self-motivation and a goal more specific than to "just get a degree," the road to graduation is tougher.

If one does not earn a degree, with a few notable exceptions, the time and money spent in college is largely wasted. The 2012 graduation rate for first-time, full-time students who began their pursuit of a bachelor's degree at a four-year degree-granting institution in fall 2006 was $59 \% .{ }^{1}$ It is in the best interest of students not only to graduate, but to graduate in a timely manner. In this paper, we explore some reasons why students graduate on time, why some students graduate in a shorter time frame, and why some do not graduate at all.

\footnotetext{
${ }^{1}$ Source: U.S. Department of Education, National Center for Education Statistics, 2014.
} 
Tinto (1975) offers a model of college dropout behavior, in which a student's experiences in college are interactions among individual, academic, and social systems, which continuously change her objectives and institutional commitment, and which can strengthen her perseverance or lead to a decline in different forms of engagement. Tinto (1975: 93) argues that, "other things being equal, one would anticipate goal commitment to be directly related to persistence in college.” In a blogpost Tinto argues that the problem of college students' retention is mainly addressed from institutional perspective to increase proportion of graduates which overlooks the main concerns of students who seek to persist to degree completion. The author writes that three aspects that influence persistence are: students' self-efficacy, sense of belonging, and perceived value of the curriculum. ${ }^{2}$ In this paper, we examine whether dedication, perseverance, and commitment to academic success are important predictors of degree completion. We measure the persistence attribute by observing students’ pursuit of a suitable graduating major.

Several researchers have undertaken related studies. Eckstein and Wolpin (1999) develop a sequential model to examine high school dropout behavior with respect to students' initial traits, such as motivation and ability, expected value of graduation, outside opportunities without completion of the degree, and value placed on leisure. The authors argue that although such initial traits could be subject to some level of change, they are largely persistent and influence the dropout phenomenon. Researchers have also documented that more time devoted to collegerelated work leads to positive outcomes (Hotz, Xu, Tienda and Ahituv, 2002; Stinebrickner and Stinebrickner, 2004, 2008); however, financial constraints impose a tradeoff between time devoted to college to perform well and outside work to meet financial needs (Tyler, 2003). Using this premise, we propose to investigate the extent to which commitment, dedication, and perseverance influence the likelihood of graduation and the length of time to graduate. Since dedication and perseverance are not directly observable, we measure these attributes by observing students' attitude in their pursuit of finding a suitable major to graduate. We proxy motivation and perseverance by observing three traits of students and examine how these affect the likelihood of degree completion: (i) early declaration of a major, which reflects motivation to find a suitable major; (ii) willingness to adjust preferences by changing major if facing difficulty in an already declared major; (iii) continuing effort to improve performance after switching, which indicates persistence and motivation to graduate.

Upon entering college, many students are not sure about their major but exert effort to find a suitable major early in their college careers. We observe the effect of declaring a major early on graduation outcomes. We argue that students who declare a major early are more engaged in finding a suitable graduating major. We predict that early declaration of a major reduces costs by decreasing the length of time to find the right major and increasing the likelihood of graduation. Even though a student's declared major in a given semester or term may not be the student's graduating major, the early declaration of a major shows commitment to finding a suitable major and determination to succeed. One possible effect of early declaration is to provide academic integration and an identity to which the student becomes committed. Such traits may eventually lead to timely graduation.

We also investigate why students change majors and how doing so influences the length of time to graduation and graduation likelihood. Students may change majors when they realize that their chosen major does not match their inherent interests. Alternatively, students struggling

\footnotetext{
${ }^{2}$ https://www.insidehighered.com/views/2016/09/26/how-improve-student-persistence-and-completion-essay
} 
in an already declared major may switch in order to improve their academic performance. Switching because of poor academic performance can be due to a student's inherent inability, to lack of support within the major, or to inadequate planning for a successful outcome. We examine whether switching related to poor performance increases the likelihood of graduation. We find that students with strong determination will adjust their expectations and preferences and will change to a more suitable major, even at the expense of delaying graduation.

After switching, the motivation to succeed and to graduate can be observed by the traits of willingness to exert effort to improve performance and desire to maintain a forward trajectory. We argue that students who change majors when facing adversity and make an effort to improve academic performance after switching increase their chances of degree completion. Likewise, an inability to improve performance after switching is more likely to lead to an unsuccessful outcome. Therefore, switching by itself does not guarantee graduation; rather, it is the effort to improve performance that is essential for degree completion.

In this study we follow the progress of a sample cohort of students from the time they begin their college career at a large research university as first-time, full-time freshmen in 2006. We follow their progress for nine years, from fall 2006 through fall 2015. We find that students who declare an academic major early are more likely to graduate earlier than those who don't declare a major early, indicating that students' willingness to find a suitable major match will lead to a successful outcome. Poorly performing students can improve graduation likelihood by switching to a suitable major; however, the cost of switching is captured in graduation delay. We analyze what factors contribute to finding a suitable graduating major, since time to graduation gets longer as the length of time to find a suitable major increases. We find that the length of time it takes to find a suitable major is correlated with how early a student tries to identify a good match. Some students come to college with focused goals, declare a major early, and do not change majors thereafter. Others students, those who are not sure of their goals but are determined to identify a suitable major, choose a major early, experiment with that choice and others, and eventually choose the right major. We find that the longer a student takes to choose an initial major, the longer it takes her to find a well-matched major.

Our results also indicate that high-performing students who identify a suitable match early are less likely to switch majors later. Although switching is associated with graduation delay, switching related to poor performance increases graduation likelihood; however, a successful outcome requires persistence in improving performance after switching. Moreover, students who declare a major early also tend to switch more. This supports our prediction that a student who picks a major early will also be more dedicated to finding a suitable one, adjusting her expectations and preferences in the event of road blocks. Conversely, inefficient switching can cause unfavorable outcomes, such as delayed graduation or failure to complete a degree.

The article proceeds as follows. Section 2 reviews related research and proposes testable hypotheses. Section 3 describes the sample collection process, variable construction, and the data. In Section 4, we present univariate comparisons between graduates and non-graduates. Section 5 presents factors that influence the likelihood of graduation. Section 6 presents our investigation of the length of time students take to declare a graduating major, and Section 7 presents our analysis of switching behavior. Section 8 concludes.

Journal of the Scholarship of Teaching and Learning, Vol. 18, No. 3, September 2018.

josotl.indiana.edu 


\section{Related Research and Conceptual Development}

\section{Related Literature}

According to a 2010 national survey by ACT on student retention by public four-year colleges and universities, the median first-year to second-year retention rate is $75 \%$, with a mean of $74 \%$. For the reported sample, the median degree completion rate is $49 \%$, with a mean of $50 \%$. The report concludes that the following factors affect student retention: students' preparedness for college, skills, personal and institutional financial resources, motivation and commitment to succeed, job demands and socio-economic status, and aspirations and goals. University programs and services to address student retention problems include measures such as internships, tutoring, use of technology in teaching, summer orientation, career counseling, student leadership development programs, and academic advising.

An extensive literature provides an understanding of various contributions of college attendance and insights into improving retention and understanding the causes of attrition. Pascarella and Terenzini (1991) provide a comprehensive literature review on how college affects students. In addition to educational accomplishment in achieving competencies and skills, the authors provide a thorough outline of how college education influences in growth of cognitive and intellectual ability, enhancement of economic outcome, and improvement of selfesteem, self-reliance, and overall quality of life. The authors argue that students' greater effort would lead to reaping greater benefits from college education. Tinto (2006) provides an overview of research on student retention in the past and discusses potential questions for the future. The author discusses literature that encompasses how institutional, cultural, socioeconomic, and diversity influence student retention. The author argues that one aspect that stems from this vast literature is that engagement matters; however, how to achieve it most effectively in different settings and for different students are not apparent. The author argues that even with vast literature most institutions are unable to translate the findings into actions that lead to higher engagement and persistence. The author writes "It is one thing to understand why students leave; it is another to know what institutions can do to help students stay and succeed." Davidson et al. (2009) report that the three most notable factors for retention are: institutional commitment, academic integration, and academic conscientiousness. ${ }^{3}$ Institutional commitment implies the degree to which a student is committed to completing her degree at one institution. Academic integration implies the extent to which a student is committed to the college curriculum and lectures and understands the link between courses and career. Academic conscientiousness is the level of a student's diligence in fulfilling the academic requirements to earn a degree.

Nandeshwar et al. (2011) show that a student's family background, family socioeconomic status, high school GPA, and standardized test scores are significant factors in predicting graduation rates, and that retention in the third year of college can be predicted using first-year retention. The authors further recommend use of variance of performance in addition to median performance to assess the efficacy of learning. Deming and Dynarski (2009) show that lower costs of attending college can substantially increase graduation rates. Engle and Tinto (2008) study students who have a household income below \$25,000 and also have parents who never went to college. This particular group demonstrates lower graduation rates and longer time to earn a college degree. Engstrom and Tinto (2008) investigate the impact of learning

\footnotetext{
${ }^{3}$ See Davidson et al. (2009) for a detailed literature review on each of the factors.
} 
communities, where students take courses together in the form of block scheduling, on the success of low income students and find that the learning communities play an important role in improving learning and persistence of this population.

Angrist, Lang, and Oreopoulos (2009) conduct a large randomized field experiment designed to assess strategies for improving the academic performance of students. Specifically, the authors investigate whether performance is affected by student services, such as peer advising and organized study groups, or incentives in the form of merit-based scholarships, or a combination of the two. Primary results show that women are more likely to take up services and incentives than men, and are also more likely to improve their academic performance after such interventions. These results are consistent with other international studies showing that female high school students reap greater benefits from intervention strategies than their male counterparts (Angrist and Lavy, 2009). Furthermore, combined interventions contribute to superior performance in the form of better grades and a lower rate of academic probation than either student services or student incentives alone.

There is a large volume of literature on retention. Some of the other notable articles that relate to college readiness as measured by high school curriculum rigorousness, performance, and college assessment tests are Adelman (1999), Kern, Fagley, and Miller (1998), Tinto (1997), among many others. Retention is also shown to be influenced by college GPA (Cabrera, Nora, and Castaneda, 1993; Mangold, Bean, Adam, Schwab, and Lynch, 2003; O’Brien and Shedd, 2001; Ishitani and DesJardins, 2002). Age, ethnicity, and socio-economic status have been shown to be important determinants of retention (Hirschy et al., 2011; Peltier, Laden, and Matranga, 1999). Lack of engagement with the institution (Astin, 1993; Pascarella and Terenzini, 1991), lack of financial aid (Fike and Fike, 2008), and the number of development or remedial courses required (Bremer et al., 2013) are also shown to be important. Some other notable work related to non-academic factors are Braxton (2000), Braxton and McClendon (2002), Kennedy, Sheckley, and Kehrhahn (2000), O’Brien and Shedd (2001), and Wyckoff (1998), among many others.

\section{Hypotheses}

The motivation to complete a college degree depends on a tradeoff between the expected economic benefit from the graduation and the cost associated with spending the time, effort, and financial resources necessary to complete a degree. In order to remain in college, students have to devote substantial time to study, forgoing or compromising on present financial gains that are available for non-college graduates. Eckstein and Wolpin (1999) relate the dropout phenomenon to a lack of motivation, an inability to perform well, a high value of leisure, a low expected future payoff from graduation, and outside opportunities. Financially constrained students will have to find the right balance between working to meet their financial needs and concentrating on academic work (Tyler, 2003). Studies suggest that more time devoted to academics leads to more successful outcomes (Hotz, Xu, Tienda, and Ahituv, 2002; Stinebrickner and Stinebrickner, 2004, 2008). Using this premise, we propose to investigate the extent to which dedication, perseverance, and commitment to succeed influence the likelihood of graduation and the length of time to graduation. Since dedication and perseverance are not directly observable, we measure these attributes by observing students' approaches to finding a suitable major that leads to graduation. We present our hypotheses below: 
Hypothesis 1: Students who commit to finding a suitable major early will reduce their search cost by shortening the length of time to find the right match and increase the likelihood of timely graduation.

Considering that time to graduation increases as the length of time to identify the ideal major increases, Hypothesis 1 is based on the premise that a commitment to finding the right fit early results in a high rate of progress toward graduation. We proxy commitment to finding a suitable major by identifying the term in which a student makes her initial declaration of a major.

Hypothesis 2: Students' willingness to change majors in order to find a more suitable one will increase their likelihood of graduation but will impose a switching cost that is captured in graduation delay.

Hypothesis 3: Students facing academic difficulties can improve performance by switching to a more suitable major; however, persistence in performance improvement is essential for successful completion of a degree.

Hypotheses 2 and 3 address determination and perseverance. A student who has strong resolve will adjust and update her expectations and preferences when facing adversity or repeated unsuccessful outcomes while pursuing a particular path, and will strive to find a more suitable discipline by changing majors, even at the expense of delaying graduation. However, performance improvement after switching will be an important determinant of her successful completion of a degree.

\section{Data, Variable Construction, and Summary Statistics}

\section{Data and Summary Statistics}

We follow the progress of 784 students from the time they began their college career at a large research university as first-time, full-time freshmen in the fall of 2006 through the fall of 2015. Our sample includes students who choose one of the business majors (finance, accounting, risk management, marketing, managerial science, etc.) at least once during their college career. The field of business offers several majors to choose from; students without a strong preference are able to take courses in different areas before deciding on one to major in. In other fields, such as, nursing, music, or history, students are more likely to be certain about their choice of a major from the beginning. Therefore we consider students who select business as a major anytime during their college tenure to provide a valid laboratory in which to examine the reasons for changing majors and whether there are benefits and costs associated with that decision. ${ }^{4}$

To test our hypotheses, we control for a set of student attributes, such as performance, availability of financial support, ethnicity, gender, and citizenship status. For each student we have grade point average (GPA) by term, cumulative GPA, declared major by term, SAT score, receipt of the HOPE scholarship and Pell grant, gender, ethnicity, citizenship status, and graduating major for students who graduate. For each term of our sample period, we observe

\footnotetext{
${ }^{4}$ We realize that our data are subject to sample selection because business students are more likely to switch majors than students in other fields. In a later study we plan to extend the sample to include students from all disciplines to test whether our predictions hold for all students, irrespective of initial major preference.
} 
each student's declared major, which allows us to identify when a student changes her major by identifying the semester where there is a switch of major.

The HOPE scholarship program was established in 1993 to pay tuition for Georgia residents who graduate with a minimum 3.0 GPA from high school and maintain a minimum 3.0 cumulative GPA in college. The program pays the cost of college tuition and fees at any public college in Georgia. ${ }^{5}$ While the HOPE scholarship is merit-based, the federal Pell grants are needbased for low-income undergraduate students. Pell grant amounts are determined in part, by a student's expected family contribution, the cost of the student's educational program, and the student's enrollment status.

Table 1 shows the descriptive statistics for our sample. \% Graduate is the percentage of students who graduated from college. A student is considered to have graduated if graduation is reported for the student at any time through the fall term 2015, which is the last reported graduating term in the sample. The first graduating term reported in the data is fall 2008, and the last graduating term reported in the data is fall 2015. \% Female is the percentage of females in sample. \% Citizen is the percentage of citizens in the sample. \% Resident Alien and \% Nonresident Alien is the percentage of students with resident and non-resident-alien status. \% White, $\%$ Black, \%Asian, \% Hispanic, and \% Other ethnicity is the percentage of students in the sample whose ethnicity is white, black, Asian, Hispanic, or other ethnic group (including non-declared), respectively. \% Students undeclared major is the percentage of students who declare a major after the first term. \% Students change major is the percentage of students who change majors in the reported terms.

Table 1: Descriptive Statistics

The table provides descriptive statistics for the sample of students from the 2006 cohort.

\begin{tabular}{|c|c|c|c|c|c|c|}
\hline & Obs. & Mean & Median & Maximum & Minimum & $\begin{array}{l}\text { Standard } \\
\text { Deviation }\end{array}$ \\
\hline \% Graduate & 784 & 65.18 & & & & \\
\hline \% Female & 784 & 53.95 & & & & \\
\hline \% Citizen & 784 & 88.01 & & & & \\
\hline \% Resident Alien & 784 & 10.08 & & & & \\
\hline \% Non-resident Alien & 784 & 1.91 & & & & \\
\hline \% White & 784 & 36.83 & & & & \\
\hline \% Black & 784 & 31.97 & & & & \\
\hline$\%$ Asian & 784 & 21.23 & & & & \\
\hline \% Hispanic & 784 & 3.20 & & & & \\
\hline \% Other ethnicity & 784 & 6.77 & & & & \\
\hline $\begin{array}{l}\text { \% Students undeclared } \\
\text { major }\end{array}$ & 784 & 38.90 & & & & \\
\hline \% Students change major & 784 & 59.31 & & & & \\
\hline Hope present & 784 & 56.10 & 55.55 & 100 & 0.00 & 35.93 \\
\hline Pell grant present & 784 & 31.03 & 10.55 & 100 & 0.00 & 36.55 \\
\hline Number of years to graduate & 511 & 4.81 & 4.00 & 9.00 & 2.00 & 1.27 \\
\hline
\end{tabular}

${ }^{5}$ Owing to a revenue shortfall, the program eliminated the payment of fees in fall 2011 and now pays a percentage of tuition that is determined each year.

Journal of the Scholarship of Teaching and Learning, Vol. 18, No. 3, September 2018. josotl.indiana.edu 


\begin{tabular}{lcccccc}
\hline $\begin{array}{l}\text { Number of undeclared major } \\
\text { terms }\end{array}$ & 784 & 0.91 & 0.00 & 14.00 & 0.00 & 1.43 \\
$\begin{array}{l}\text { Number of times change } \\
\text { major }\end{array}$ & 784 & 0.90 & 1.00 & 6.00 & 0.00 & 0.96 \\
$\begin{array}{l}\text { Terms to declare graduating } \\
\text { major }\end{array}$ & 511 & 4.62 & 4.00 & 18.00 & 0.00 & 3.57 \\
$\begin{array}{l}\text { Performance } \\
\text { Term GPA }\end{array}$ & 784 & 2.71 & 2.89 & 4.10 & 0.00 & 0.80 \\
Cumulative GPA & 784 & 2.80 & 2.96 & 4.10 & 0.00 & 0.72 \\
Graduating GPA & 480 & 3.09 & 3.09 & 4.20 & 2.04 & 0.40 \\
SAT & 733 & 1083.64 & 1090.00 & 1450 & 660 & 115.38 \\
\hline
\end{tabular}

Hope present is the percentage of terms a student has the HOPE scholarship available. Pell grant present is the percentage of terms a student has the Pell grant available. Number of years to graduate is the total number of years a student takes to graduate and therefore includes only students who have graduated. Number of undeclared major terms is the number of terms before a student declares a term major. Number of times change major is the number of times a student changes majors. Terms to declare graduating major is the number of terms a student takes to declare the graduating major. Term GPA and Cumulative GPA are the average of the term GPA and the cumulative GPA, respectively. Graduating GPA is the final institutional GPA upon graduation. SAT is the student's SAT score.

In the nine-year time frame from 2006 through 2015, 65.2\% of the students in our sample graduated. There are more female students (54\%) in the sample than there are male students. The percentage of citizens is $88 \%$. The rest of the students are resident aliens or non-resident aliens. On average, about $59.3 \%$ students change majors. Average time to graduation is 4.8 years. The average number of undeclared major terms is 0.91 and the maximum is $14 .{ }^{6}$ The average number of times students change major is 0.90 and the maximum is 6 . The average number of terms students take to declare a graduating major is 4.62 and the maximum number is 18 . On average, about $56 \%$ and $31 \%$ of the students receive financial aid in the form of a HOPE scholarship and Pell grant, respectively. Incoming freshmen had an average SAT of 1084. The average term and cumulative GPA is 2.71 and 2.80, respectively. Graduates have an average overall GPA of 3.09.

\section{Switching Majors: Comparison between Graduates and Non-graduates}

Figure 1 shows the percentage of students relative to number of years to graduate. As Figure 1 shows, about $33 \%$ of students graduated in four years or less, about $19 \%$ of students graduated in five years, a little more than $5 \%$ of students graduated in six years, less than $5 \%$ graduated in seven years, and about $3 \%$ took eight or more years to graduate.

In order to examine which attributes contribute to timely graduation and which are deterrents, we examine how switching majors affects how long it takes to graduate. Figure 2 compares switching behavior for graduates and non-graduates. The graduates are further broken down into those who graduate within four, five, six, seven, and eight or more years. We observe that, on average, graduates switch majors more often than non-graduates.

\footnotetext{
${ }^{6}$ There are three terms in a year: spring, summer, and fall.
} 
Within the graduate pool we observe a monotonic increase in the percentage of students switching majors as the number of years to graduate increases. About $62 \%$ of students who graduate in four years or less switch majors, whereas about $70 \%, 73 \%$, and $77 \%$ of students switch majors among the pool who graduate in five, six, and seven years, respectively. Of those who take eight or more years to graduate, a very high percentage, about $87 \%$, switch majors. Students who graduate in a timely manner are more likely to be high-performing students, and they are more likely to have identified a major early that is a suitable match for them. On the other hand, students' graduation might be delayed as they spend more years seeking a suitable major. This switching behavior can be due to not being able to identify a major that matches the student's interests and career goals; or it could be due to poor performance within the major and the need to find a field of study that more closely matches the student's ability. The association of changing majors with a longer time to graduate suggests that changing majors delays graduation. It suggests the importance of assisting students in finding a suitable major early in order to achieve timely graduation. The fact that non-graduates change majors less often than graduates implies that stubbornness - sticking with an already chosen discipline that does not fit the student's ability and interests - may result in failure to complete the program, and that having an open mind about changing majors might assist students to graduate. In Section 5 we investigate how switching behavior affects graduation likelihood, and in Section 7 we analyze what influences students to switch majors.

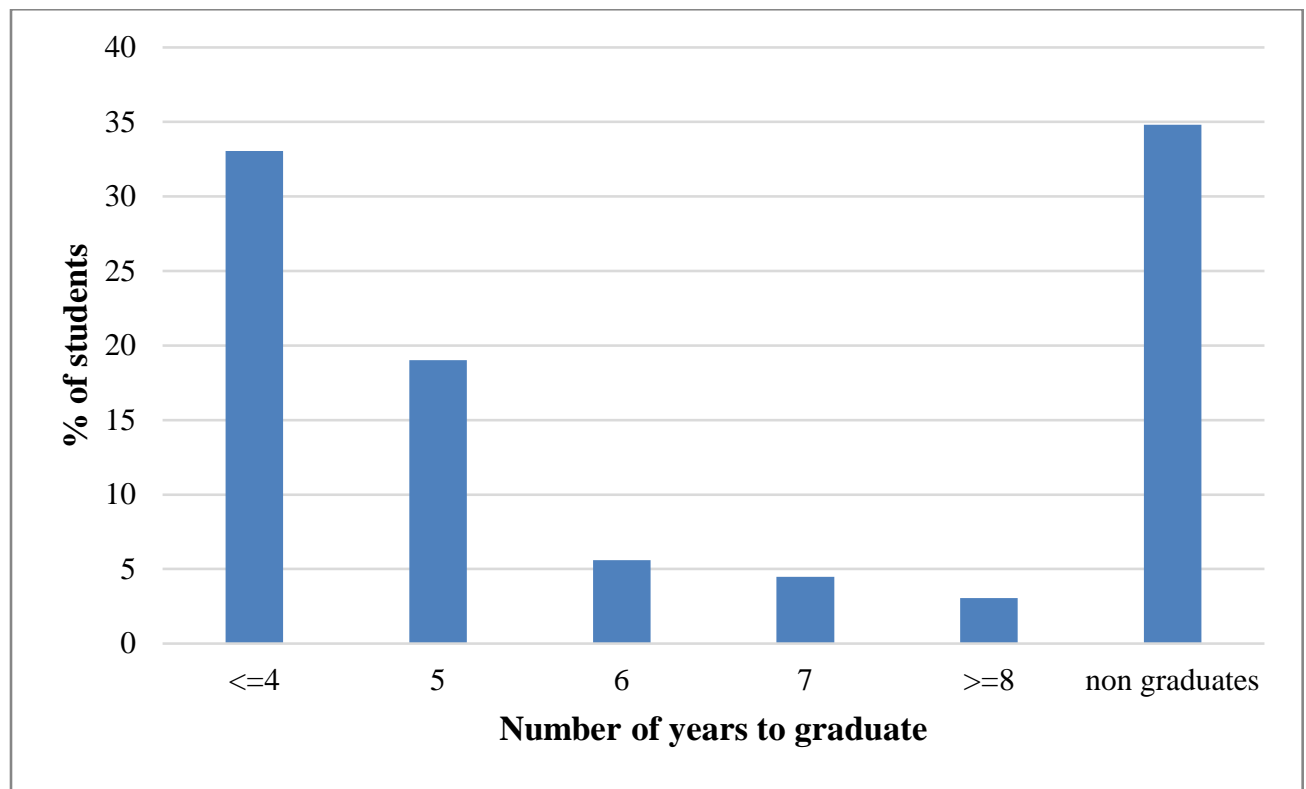

Figure 1: Percentage of students who graduated and who did not graduate 


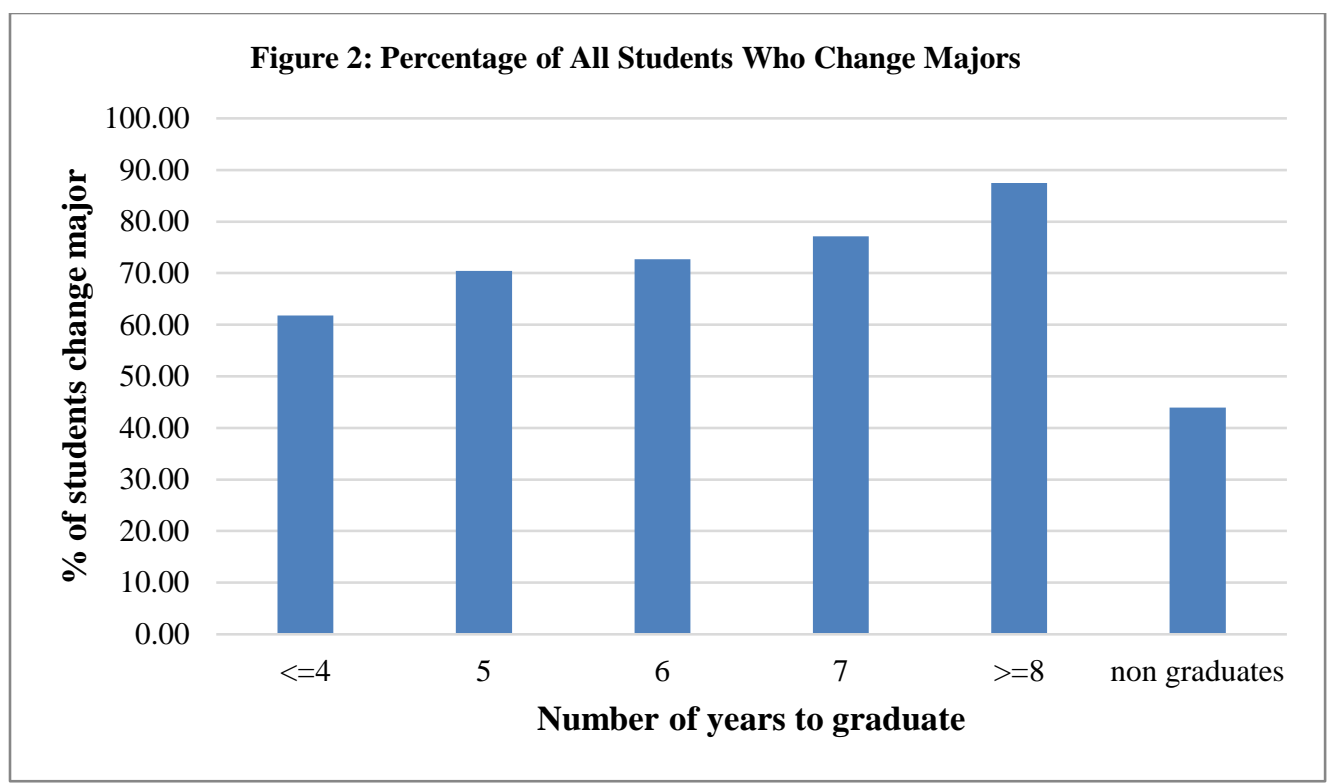

Figure 2: Percentage of all students who change majors

Number of Terms Students Take to Declare a Graduating Major

Figure 3 shows the relationship between the average number of terms it takes students to declare a graduating major and the number of years to graduation. It is logical to conjecture that the longer it takes students to declare a graduating major, the more it will delay their graduation. We observe a monotonic increase in the number of terms to declare a graduating major with the number of years to graduate. In Section 6, we investigate the factors that influence how long it takes students to declare a major that leads to graduation.

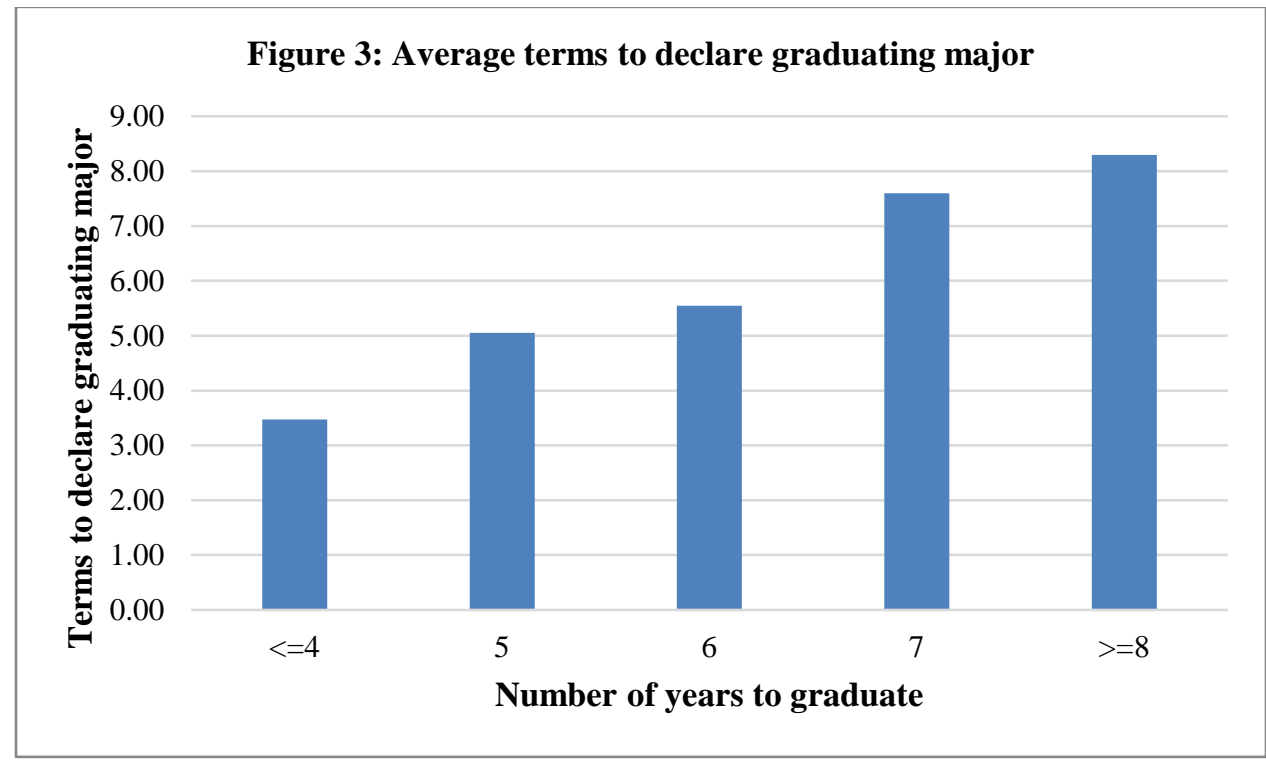

Figure 3: Average number of terms to declare graduating major and number of years to graduate 


\section{Univariate Comparison of Graduates and Non-graduates}

Of the 784 sample students, 511 (65.18\%) graduated within nine years. Panel A of Table 2 compares the characteristics of students who graduated with those of students who did not graduate. Graduates have significantly higher term and cumulative GPAs and are more likely to have received a HOPE scholarship. ${ }^{7}$ We further observe that non-graduates have a higher average SAT score than graduates; however, the difference is not significant.

Table 2: Difference between students who graduate and students who do not graduate Panel A compares students who graduate with students who do not graduate. Panel B compares students who graduate within 4 years with students who graduate in more than 4 years. Mean values and $p$-values for difference in means are presented.

\begin{tabular}{llll}
\hline Panel A & & & \\
\hline & $\begin{array}{l}\text { Graduate } \\
\text { (Obs. 511) }\end{array}$ & $\begin{array}{l}\text { Do Not Graduate } \\
\text { (Obs. 273) }\end{array}$ & $\begin{array}{l}\text { p-Value for } \\
\text { Difference }\end{array}$ \\
\hline \% Female & 54.99 & 52.01 & 0.42 \\
\% Citizen & 87.67 & 88.64 & 0.69 \\
\% Resident Alien & 11.15 & 8.06 & 0.17 \\
\% Non-resident Alien & 1.17 & 3.29 & 0.04 \\
Hope present & 58.37 & 51.82 & 0.01 \\
Pell grant present & 32.42 & 28.44 & 0.14 \\
\% White & 33.53 & 43.01 & 0.00 \\
\% Black & 31.76 & 32.35 & 0.87 \\
\% Asian & 23.53 & 16.91 & 0.03 \\
\% Hispanic & 3.92 & 1.84 & 0.11 \\
\% Other Ethnicity & 7.26 & 5.89 & 0.47 \\
\% Students undeclared major & 37.77 & 41.02 & 0.37 \\
\% Students change major & 67.51 & 43.95 & 0.00 \\
Number of undeclared major terms & 0.89 & 0.95 & 0.58 \\
Number of times change major & 1.02 & 0.69 & 0.00 \\
SAT & 1087.49 & 1076.38 & 0.21 \\
Term GPA & 3.06 & 2.06 & 0.00 \\
Cumulative GPA & 3.06 & 2.31 & 0.00 \\
\hline
\end{tabular}

\begin{tabular}{llll}
\hline Panel B & & & \\
\hline & $\begin{array}{l}\text { Graduate } \leq 4 \text { years } \\
\text { (Obs. 259) }\end{array}$ & $\begin{array}{l}\text { Graduate }>4 \text { years } \\
\text { (Obs. 252) }\end{array}$ & $\begin{array}{l}\text { p-Value for } \\
\text { Difference }\end{array}$ \\
\hline \% Female & 60.23 & 49.60 & 0.01 \\
Hope present & 73.35 & 42.99 & 0.00 \\
Pell grant present & 24.87 & 40.18 & 0.00 \\
\hline
\end{tabular}

${ }^{7}$ The HOPE scholarship is intended to motivate students with modest achievement who maintain a GPA average above 3.0 in college. Dynarski (2002, 2005) and Seligman et al. (2004) examine the effect of such programs on students' college attendance and graduation; they report that such programs give students an incentive to improve their academic performance and improve graduation rates. Cornwell et al. (2006) examine the effect of HOPE grants on college enrollments in Georgia and report that HOPE increased freshman enrollment by 5.9\%. 


\begin{tabular}{llll}
\hline SAT & 1085.31 & 1089.78 & 0.67 \\
Mean Term GPA & 3.24 & 2.88 & 0.00 \\
Graduation GPA & 3.24 & 2.93 & 0.00 \\
\% Students undeclared major & 35.13 & 40.48 & 0.21 \\
\% Students change major & 61.78 & 73.41 & 0.00 \\
Number of undeclared major terms & 0.78 & 1.01 & 0.08 \\
Number of times change major & 0.87 & 1.17 & 0.00 \\
Terms to declare graduating major & 3.47 & 5.80 & 0.00 \\
\hline
\end{tabular}

In Panel A, we find that almost $68 \%$ of graduates change majors and about $44 \%$ of nongraduates do; a smaller percentage of graduates (about 38\%) have undeclared major terms than their non-graduate counterparts (about 41\%). These results lead us to believe that finding a suitable major is vital to graduation. In Panel B, we consider graduates only and divide the pool with respect to how long they take to graduate (4 years or less and greater than 4 years). The main findings are that female students, HOPE Scholars, students with higher term GPAs, and students who declare a major sooner all graduate earlier. These results are consistent with Panel A. Students who switch majors take longer to graduate. About $62 \%$ of students who graduate in less than four years switch majors, whereas about $73 \%$ of students who take longer than four years switch majors (Panel B). In unreported results similar patterns holds when we compare 5 and 6 years to graduate vs. longer graduation years. These results, along with those in Panel A, suggest that although switching may be important to improve graduation outcome, the cost of switching is observed in graduation delay. This relates to our Hypothesis 2 that switching increases the likelihood of graduation but is associated with graduation delay. In Tables 3 and 4 we test this prediction in a regression setting.

\section{Students’ Likelihood of Graduation}

Table 3 presents the odds ratio of logistic regression results of the likelihood of students to graduate. The dependent variable in model 1 is Graduate, which has a value equal to one if a student in the 2006 cohort graduates by fall 2015 and zero otherwise. Models 2 to 4 show results for graduating in four, five, and six years, respectively. The dependent variable in model 2 is Graduate within 4 years, which takes a value equal to one if the student graduates within 4 years, and 0 otherwise. Similarly, the dependent variable in model 3 (4) is Graduate within 5(6) years, which takes a value equal to one if the student graduates within 5(6) years, and 0 otherwise. The number of observations in all the models represents the number of students in the sample with all the independent variables present. The independent variable Number of undeclared major terms is the number of terms before a student declares a term major. Number of times change major is the number of times a student changes majors. All other independent variables are defined in Appendix Table A.1. Values of $t$-statistics are reported in parentheses and are based on robust standard errors clustered at the students' ethnicity level. All models in Table 3 include a student ethnicity dummy.

Our main empirical questions are related to how the search for a suitable major affects graduation likelihood. In particular, we want to observe whether an early declaration of major and switching majors influence graduation. We observe the effect of the independent variables Number of undeclared major terms and Number of times change major on graduation likelihood

Journal of the Scholarship of Teaching and Learning, Vol. 18, No. 3, September 2018. josotl.indiana.edu 
and timely graduation, while we control for performance, gender, citizenship status, and financial aid availability.

The results in Table 3 confirm that students who have a higher term GPA are more likely to graduate and graduate sooner. In model 1 the effect of Number of undeclared major terms on graduation likelihood is insignificant; however, in models 2 to 4 of Table 3, the independent variable has negative and significant effects, suggesting that students who delay picking a major are less likely to graduate on time.

Table 3: Logistic Regression for Likelihood of Graduation

The table presents the odds ratio of logistic regression results for the likelihood of graduation.

\begin{tabular}{lllll}
\hline Logistic Regression & \multicolumn{5}{l}{} \\
\hline & Graduate & \multicolumn{2}{l}{ Graduate within $\begin{array}{l}\text { Graduate within } 5 \\
\text { years }\end{array}$} & $\begin{array}{l}\text { Graduate within } 6 \\
\text { years }\end{array}$ \\
\hline & $(1)$ & $(2)$ & $(3)$ & $(4)$ \\
\hline Number of undeclared major & & & & \\
terms & 1.092 & $0.927^{* * *}$ & $0.911^{* * *}$ & $0.899^{* * *}$ \\
& $(1.48)$ & $(-3.33)$ & $(-4.84)$ & $(-6.02)$ \\
Number of times change & & & & \\
major & $1.438^{* * *}$ & 0.949 & 1.077 & $1.144^{* *}$ \\
& $(5.25)$ & $(-0.61)$ & $(1.02)$ & $(2.03)$ \\
Term GPA & $33.288^{* * *}$ & $9.755^{* * *}$ & $14.194^{* * *}$ & $13.945^{* * *}$ \\
& $(5.82)$ & $(4.93)$ & $(4.52)$ & $(4.65)$ \\
SAT & 1.000 & $0.998^{* * *}$ & $0.999^{* *}$ & 0.999 \\
& $(0.60)$ & $(-3.80)$ & $(-1.98)$ & $(-1.40)$ \\
Hope present & $0.141^{* * *}$ & $1.912^{*}$ & 0.901 & 0.631 \\
& $(-3.62)$ & $(1.68)$ & $(-0.45)$ & $(-1.41)$ \\
Pell grant present & 1.736 & $0.454^{* *}$ & 0.787 & 0.764 \\
& $(1.10)$ & $(-2.08)$ & $(-0.54)$ & $(-0.57)$ \\
Female & 1.039 & 1.203 & 1.226 & 1.044 \\
& $(0.43)$ & $(0.93)$ & $(1.24)$ & $(0.32)$ \\
Citizen & $1.705^{* *}$ & 1.102 & 1.256 & 1.331 \\
& $(2.52)$ & $(0.26)$ & $(0.60)$ & $(0.97)$ \\
Constant & $0.000^{* * *}$ & $0.003^{* * *}$ & $0.001^{* * *}$ & $0.0011^{* * *}$ \\
& $(-4.82)$ & $(-7.46)$ & $(-3.32)$ & $(-3.61)$ \\
Observations & & & & 731 \\
Ethnicity dummy & 731 & 731 & Yes & Yes \\
Pseudo R-squared & Yes & Yes & 0.317 & 0.319 \\
\hline
\end{tabular}

Note: Values of $t$-statistics are reported in parentheses and are based on robust standard errors clustered at the students' ethnicity level. ${ }^{* * *},{ }^{* *}$, and $*$ indicate significance at the $1 \%, 5 \%$, and $10 \%$ levels, respectively.

Supporting our Hypothesis 1, our results suggest that early declaration of a major increases the likelihood of timely graduation, which implies that students who declare a major early are more engaged in the search for a suitable major and hence are more likely to complete their degree early. We later show in Table 4 that early selection of a major influences the time it 
takes to find a suitable major. Even though the declared major in a given term may not be the student's graduating major, early declaration of a major shows the commitment of the student to finding a suitable major and her determination to give the major a try.

The independent variable Number of times change major has a positive significant effect in models 1 and 4, suggesting that switching majors increases graduation likelihood. The nonsignificant effect of Number of times change major in models 2 and 3 with the dependent variable Graduate within 4 years and Graduate within 5 years, respectively, suggests that changing majors imposes a graduation delay. Overall, the results suggest that changing majors increases the likelihood of graduation but is associated with a longer time to graduation, which supports our Hypothesis 2. We provide further evidence in Table 4 that changing majors delays graduation. Because switching majors may indicate struggling students' commitment to finding a major that matches their interests and skills, the likelihood of graduation increases. In Section 7 , we investigate the reasons for switching behavior in detail.

\section{Analysis of Length of Time to Declare a Graduating Major}

Given that students graduate sooner if they are able to find a suitable major early in their college career, we wish to analyze the factors affecting the number of terms a student completes before declaring a graduating major. Table 4 shows our results and includes a sub-sample of students who graduate by fall 2015. The dependent variable is Terms to Declare Graduating Major, which measures the number of terms a student takes to declare the graduating major. We match the term major with the graduating major to identify the term in which the student chooses the graduating major. The number of terms before a match is found is the number of terms it takes a student to declare a graduating major. Model 1 includes the full sample of graduates. Models 2, 3 , and 4 analyze sub-samples of students graduating within four years, five years, and six to seven years, respectively.

The independent variable Number of undeclared major terms is the number of terms before a student declares a term major. Number of times change major is the number of times a student changes majors. All other independent variables are defined in Appendix Table A.1. All models include student ethnicity fixed effects and include graduating degree level fixed effects. Values of $t$-statistics are reported in parentheses and are based on robust standard errors clustered at the students' ethnicity level.

The results show that students with higher term GPAs take less time to declare a graduating major. This suggests that students who are performing well tend to be more confident in selecting their graduating major early. These students have little need to reorient themselves in order to find a suitable major. These students' high performance could be due to their ability to identify a major that matches their interests or to their choice of a major that requires skills that match their abilities.

Journal of the Scholarship of Teaching and Learning, Vol. 18, No. 3, September 2018.

josotl.indiana.edu 
Table 4: Regression Analysis of Terms to Declare Graduating Major

The dependent variable is Terms to Declare Graduating Major, which measures the number of terms a student takes to declare the graduating major.

\begin{tabular}{lllll}
\hline Dependent Variable: Terms to Declare Graduating Major & & \\
\hline & Full Sample & $\begin{array}{l}\text { Graduate within } 4 \\
\text { years }\end{array}$ & $\begin{array}{l}\text { Graduate in } 5 \\
\text { years }\end{array}$ & $\begin{array}{l}\text { Graduate in } 6 \text { to } \\
7 \text { years }\end{array}$ \\
\hline VARIABLES & $(1)$ & $(2)$ & $(3)$ & $(4)$ \\
Number of undeclared major & & & & \\
terms & $0.730^{* * *}$ & $0.724^{* * *}$ & $0.596^{* *}$ & $0.831^{* *}$ \\
& $(16.70)$ & $(8.84)$ & $(2.87)$ & $(3.77)$ \\
Number of times change major & $2.164^{* * *}$ & $1.960^{* * *}$ & $2.374^{* * *}$ & $2.115^{* * *}$ \\
& $(22.81)$ & $(17.56)$ & $(9.79)$ & $(4.62)$ \\
Term GPA & $-1.489^{* * *}$ & -0.879 & -0.996 & -0.357 \\
& $(-4.06)$ & $(-1.59)$ & $(-0.90)$ & $(-0.20)$ \\
SAT & 0.000 & -0.001 & 0.000 & $0.003^{*}$ \\
& $(0.10)$ & $(-1.36)$ & $(0.06)$ & $(2.07)$ \\
Hope present & -0.442 & 0.487 & -1.036 & -0.076 \\
& $(-1.35)$ & $(1.03)$ & $(-0.82)$ & $(-0.06)$ \\
Pell grant present & $1.121^{* *}$ & $0.536^{*}$ & 0.798 & 0.975 \\
& $(2.52)$ & $(2.03)$ & $(1.25)$ & $(1.27)$ \\
Female & 0.046 & 0.259 & 0.178 & $-1.367 * *$ \\
& $(0.14)$ & $(1.20)$ & $(0.18)$ & $(-2.58)$ \\
Citizen & -0.131 & -0.581 & 0.917 & 0.603 \\
& $(-1.39)$ & $(-1.69)$ & $(0.88)$ & $(0.32)$ \\
Constant & $6.078^{* * *}$ & $4.723^{* * *}$ & 3.607 & 0.930 \\
& $(9.79)$ & $(4.49)$ & $(1.58)$ & $(0.21)$ \\
Observations & & & & \\
Adjusted R-squared & 478 & 245 & 138 & 74 \\
Ethnicity F.E. & 0.473 & 0.504 & 0.374 & 0.282 \\
Graduation degree F.E & Yes & Yes & Yes & Yes \\
\hline
\end{tabular}

Note: Values of $t$-statistics are reported in parentheses and are based on robust standard errors clustered at the students' ethnicity level. ${ }^{* * *}, * *$, and * indicate significance at the $1 \%, 5 \%$, and $10 \%$ levels, respectively.

Further, the results in Table 4 show that students who have a larger number of undeclared major terms take longer to declare their graduating major. We note that a term major can be different from or the same as the graduating major. Students who are certain about the career path they want to pursue declare a term major early, are less prone to changing majors, and take fewer terms to declare a graduating major. However, students who are not sure what career they want to pursue at an early stage but are eager to identify one may declare a major early as a way of experimenting and gradually navigate toward a suitable major. Supporting our Hypothesis 1, the results in Table 4 suggest that students who declare a term major early take fewer terms to declare a graduating major; that is, they take less time to find a suitable major. A positive and significant effect of Number of times change major indicates that a student's willingness to find a major that is suitable for her by switching from one declared major to another will increase the number of terms it takes her to declare a graduating major. This supports our Hypothesis 2 that 
switching leads to graduation delay. The availability of financial aid does not seem to have any effect on the length of time it takes to find the graduating major.

\section{Analysis of Students’ Reasons for Switching Majors}

\section{Why Students Switch Majors}

In Table 5 we compare the attributes of students who switch majors with those of students who do not switch majors. We further divide each category into graduates and non-graduates. The univariate comparison indicates that poor performance may prompt students to switch majors to increase their chances of graduating. Non-switching graduates have higher term and cumulative GPAs of about 3.15 and 3.16 respectively, about 61\% have a major term GPA above the median value, and 66\% receive the HOPE scholarship and take less time to graduate.

In comparison with non-switching graduates, students who switch majors and eventually graduate have lower term and cumulative GPAs (3.02 and 3.01, respectively), 55\% receive the HOPE scholarship, and 50\% have an above-median major term GPA and take longer to graduate. The differences between these attributes of switching and non-switching graduates are significant, suggesting that although poor performance may induce switching behavior, switching increases students' chances of successfully completing a degree.

One notable point is that non-switching non-graduates were significantly more likely to have received a HOPE scholarship than their switching non-graduate counterparts. This suggests that although at some point in time these non-switching students performed well and received a HOPE scholarship, as their performance declined they failed to take any initiative to improve their chances of graduation.

We also observe that these non-switching non-graduates have a higher number of undeclared major terms than students who switched and did not graduate. Overall, the number of undeclared major terms is lower for students who switched majors, suggesting that students who declare a major initially show some proactive effort to find a suitable major to graduate.

Journal of the Scholarship of Teaching and Learning, Vol. 18, No. 3, September 2018.

josotl.indiana.edu 
Journal of the Scholarship of Teaching and Learning, Vol. 18, No.3, September 2018, pp..

doi: 10.14434/josotl.v18i3.22649

\section{Table 5: Switch vs. No Switch}

The table compares students who switch majors with students who do not switch majors. Both the categories are further divided into graduates and non-graduates.

\begin{tabular}{|c|c|c|c|c|c|c|c|c|}
\hline \multicolumn{5}{|c|}{ Mean } & \multicolumn{4}{|c|}{ p-Value for Difference } \\
\hline & \multicolumn{2}{|c|}{ Switch Major } & \multicolumn{2}{|c|}{ Do Not Switch Major } & \multicolumn{2}{|c|}{$\begin{array}{l}\text { Graduates and } \\
\text { Non- graduates }\end{array}$} & \multicolumn{2}{|c|}{$\begin{array}{l}\text { Students Who Switch } \\
\text { and Don't Switch }\end{array}$} \\
\hline & $\begin{array}{l}\text { Graduates } \\
\text { (obs. }=345 \text { ) }\end{array}$ & $\begin{array}{l}\text { Non- } \\
\text { graduates } \\
\text { (obs.=120) }\end{array}$ & $\begin{array}{l}\text { Graduates } \\
\text { (obs.=166) }\end{array}$ & $\begin{array}{l}\text { Non- } \\
\text { graduates } \\
\text { (obs.=153) }\end{array}$ & Switch & $\begin{array}{l}\text { No- } \\
\text { Switch }\end{array}$ & Graduates & $\begin{array}{l}\text { Non- } \\
\text { graduates }\end{array}$ \\
\hline Term GPA & 3.02 & 2.31 & 3.15 & 1.86 & 0.00 & 0.00 & 0.00 & 0.00 \\
\hline Cumulative GPA & 3.01 & 2.56 & 3.16 & 2.12 & 0.00 & 0.00 & 0.00 & 0.00 \\
\hline Hope present & 54.73 & 39.88 & 65.95 & 61.18 & 0.00 & 0.24 & 0.00 & 0.00 \\
\hline Pell grant present & 34.84 & 34.26 & 27.39 & 23.87 & 0.88 & 0.39 & 0.03 & 0.02 \\
\hline $\begin{array}{l}\text { Major GPA above median } \\
(\%)\end{array}$ & 50.33 & 28.79 & 61.10 & 22.83 & 0.00 & 0.00 & 0.00 & 0.14 \\
\hline $\begin{array}{l}\text { Number of undeclared major } \\
\text { terms }\end{array}$ & 0.65 & 0.74 & 1.41 & 1.12 & 0.44 & 0.12 & 0.00 & 0.02 \\
\hline $\begin{array}{l}\text { Terms to declare graduating } \\
\text { major }\end{array}$ & 6.07 & & 1.61 & & & & 0.00 & \\
\hline Number of years to graduate & 4.93 & & 4.54 & & & & 0.00 & \\
\hline
\end{tabular}


In the multivariate analysis in Table 6, the dependent variable is Number of times change major, which is the number of times a student changes her term major during the time spent in college. Models 1 and 2 analyze the entire cohort irrespective of whether a student graduates or not. Models 3 and 4 perform a similar analysis with the sub-sample of graduating students. All models include ethnicity fixed effects. Models 3 and 4 include graduating degree level fixed effects. The independent variables are defined in Appendix Table A.1. Values of $t$-statistics are reported in parentheses and are based on robust standard errors clustered at the students' ethnicity level. The negative and significant effect of Number of undeclared major terms suggests that students who declare a major early are more likely to switch majors later. This supports our prediction that a student who picks a major early also shows a willingness to find a suitable one and therefore adjusts her expectations and preferences if she faces adversity or has a change of heart.

Term GPA has positive significant effects in models 1 and 2; which suggest that, independent of graduation, well-performing students change majors. In models 2 , we find more switching behavior, especially for students who take 5 to 7 years to graduate as compared to the rest of the non-graduate sample and students who delay graduation further. These results suggest that proactively seeking a suitable major match can lead to a successful outcome, even at the expense of delayed graduation. Within the graduating sample, less switching is observed for students graduating within four years.

These results support our prediction that a student who realizes that the current major is not a suitable match, given a determination to graduate, will navigate her way to a suitable major and eventually graduate. Lack of flexibility and willingness to adjust might result in not graduating or dropping out of college altogether. Conversely, inefficient switching can also lead to delayed graduation.

Table 6: Regression Analysis of Number of Times Change Major

The dependent variable Number of times change major is the number of times a student from the 2006 cohort changes majors. Models 1 and 2 perform analysis on the entire cohort irrespective of whether the students graduated, and models 3 and 4 perform analysis on students who graduated.

Dependent variable: Number of times change major

\begin{tabular}{lllll}
\hline & Full Sample & \multicolumn{2}{l}{ Graduating Sample } \\
\hline VARIABLES & $(1)$ & $(2)$ & $(3)$ & $(4)$ \\
\hline \multirow{3}{*}{ Number of undeclared major terms } & $-0.139^{* * *}$ & $-0.140^{* * *}$ & $-0.134^{* * *}$ & $-0.139^{* * *}$ \\
& $(-5.26)$ & $(-5.48)$ & $(-5.82)$ & $(-5.53)$ \\
Term GPA & $0.243^{* * *}$ & $0.203^{* * *}$ & -0.202 & -0.134 \\
& $(6.41)$ & $(5.73)$ & $(-1.33)$ & $(-0.93)$ \\
SAT & -0.000 & -0.000 & -0.000 & -0.000 \\
& $(-0.61)$ & $(-0.74)$ & $(-1.19)$ & $(-1.24)$ \\
Hope present & $-0.803^{* * *}$ & $-0.737^{* * *}$ & $-0.280^{*}$ & -0.209 \\
Pell present & $(-26.05)$ & $(-11.89)$ & $(-1.99)$ & $(-1.23)$ \\
& 0.108 & 0.076 & -0.082 & -0.134 \\
Female & $(1.58)$ & $(0.86)$ & $(-0.47)$ & $(-0.70)$ \\
& 0.086 & 0.090 & 0.099 & 0.106 \\
& $(1.34)$ & $(1.33)$ & $(1.27)$ & $(1.24)$
\end{tabular}




\begin{tabular}{lllll} 
Citizen & 0.162 & 0.156 & 0.005 & -0.012 \\
& $(0.91)$ & $(0.89)$ & $(0.03)$ & $(-0.08)$ \\
Graduate within 4yrs & & 0.053 & & $-0.393^{*}$ \\
& & $(0.80)$ & & $(-2.10)$ \\
Graduate in 5yrs & & $0.181^{* * *}$ & & -0.225 \\
& & $(3.30)$ & & $(-1.25)$ \\
Graduate in 6to7yrs & & $0.281^{*}$ & & -0.202 \\
& & $(1.74)$ & & $(-0.89)$ \\
Constant & 0.789 & $0.857^{*}$ & $2.721^{* * *}$ & $2.862^{* * *}$ \\
& $(1.80)$ & $(2.00)$ & $(3.43)$ & $(3.73)$ \\
Observations & 731 & 731 & 478 & 478 \\
Adjusted R-squared & 0.120 & 0.125 & 0.139 & 0.142 \\
Ethnicity F. E & Yes & Yes & Yes & Yes \\
Graduating-degree F. E. & & & Yes & Yes \\
\hline
\end{tabular}

Note: Values of $t$-statistics are reported in parentheses and are based on robust standard errors clustered at the students' ethnicity level. ***, **, and * indicate significance at the $1 \%, 5 \%$, and $10 \%$ levels, respectively.

Our results so far do not differentiate between change of major due to poor performance and change of major due to shifting interests and goals. In the next section, we identify switching that is likely to be triggered by poor performance and switching that is more likely to be related to changed goals or preferences. For these students we compare performance after switching and graduation outcomes.

\section{Performance of Students Before and After Switching Majors}

In Table 7, we analyze students' performance before and after switching majors to test our Hypothesis 3 that while poor performers can improve performance by switching to a suitable major, persistence in performance improvement is essential for successful completion. The sample includes only students who switch majors. Panel A of Table 7 reports the mean term GPA before and after switching. TermGPAis provided for terms $(t-1)$, $t$, and $(t+1)$ relative to a given switch term $t$. Panel B reports the percentage of switching students with an above-median term GPA in their declared major. Here again $(t-1), t$, and $(t+1)$ are relative to a given switch term $t$.

The results in Panel A show that, for students who changed majors, term GPA is significantly lower one term before switching than it is in the following terms, suggesting that low performance causes students to switch majors. Moreover, a comparison of graduates and non-graduates shows that students who significantly improve performance after switching will eventually graduate. The results in Panel B show that, before switching, 38\% of students who later switch majors (graduates and non-graduates) have an above-median term GPA, while after switching more than $44 \%$ have an above-median GPA. Reiterating our findings in Panel A, switching graduates continue to show improvement in performance after switching, while nongraduates are unable to improve performance after switching majors. 
Journal of the Scholarship of Teaching and Learning, Vol. 18, No.3, September 2018, pp..

doi: 10.14434/josotl.v18i3.22649

\section{Table 7: Term GPA and Percentage of Above-Median Major GPA for Students Switching Majors}

Panel A reports mean values of term GPA for students who switch majors in term $t$. Panel B reports the percentage of students with an above-median GPA in the declared major when students switch in term $t$. AboveMedianGPA is an indicator variable equal to 1 if student GPA is above the median GPA in the major declared by the student for the given term, where $(t-1), t, a n d(t+1)$ are relative to a given switch term $t$.

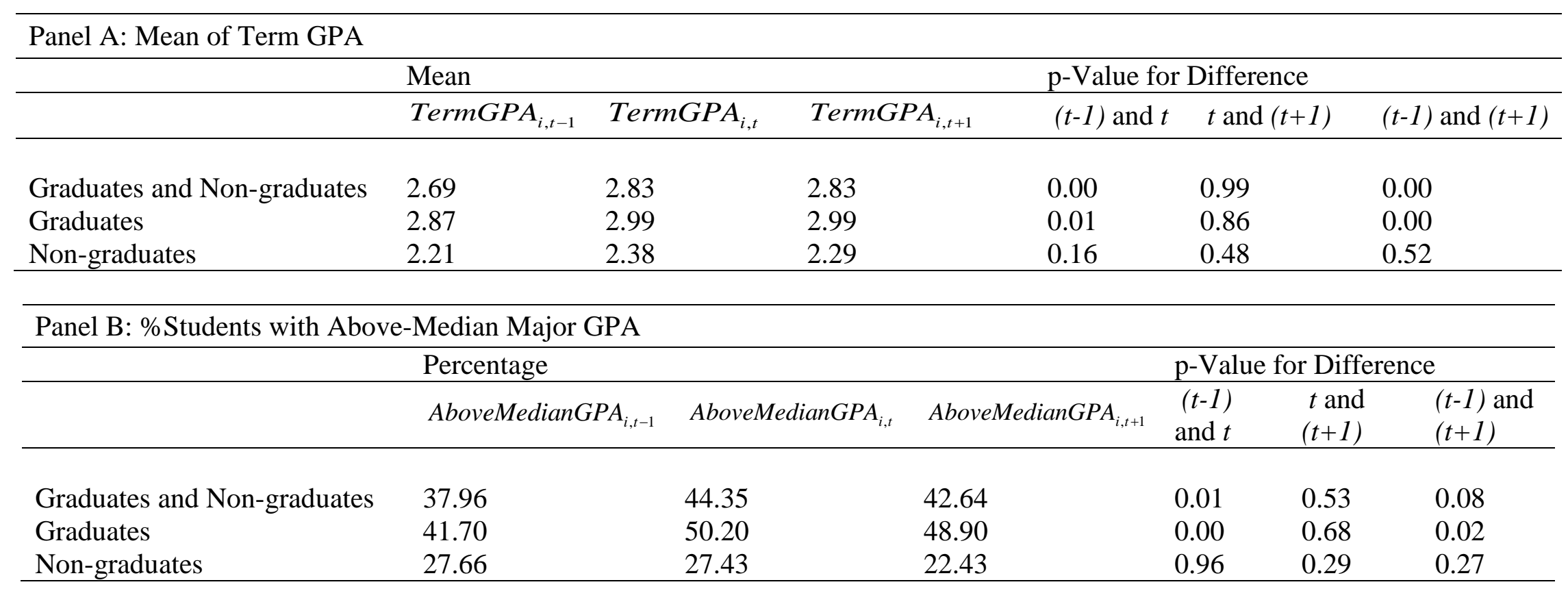


Supporting our Hypothesis 3, these results suggest that although switching is mainly driven by poor performance in the declared major and willingness to find a suitable major to improve the chances of graduation, performing well is the key to completing a degree. For students who fail to graduate, we observe no significant improvement in performance after switching; instead, their performance declines. This supports our prediction that making an effort to improve performance after switching is essential to degree completion. Moreover, inefficient switching is more likely to lead to an unsuccessful outcome.

We next examine how performance prior to switching predicts graduation likelihood and other attributes that portray students' motivation and engagement. Switching not related to poor performance but to shifting interests or career goals may have different implications for graduation outcome. On the basis of this premise, Table 8 compares students with above- and below-median major GPAs one term prior to switching. The sample includes only students who switch majors. Above- (below-) median switchers include students with performance above (below) the median GPA for the declared major one term before the switch. For the two categories, Panel A of Table 8 reports the percentage of students who graduate, number of years to graduate, terms to declare a graduating major, and terms to complete graduation after declaration of graduating major. The p-values for the differences in mean between each category are also reported.

We observe that above-median performers prior to switching have a high graduation rate of about $84 \%$, whereas below-median performers have a low graduation rate of about $68 \%$. Moreover, above-median performers take less time overall to graduate, and the length of time between identifying the graduating major and graduation is also shorter. These results suggest that switching not related to poor performance leads to faster graduation and is likely to be driven by shifting interests and career paths. Higher graduation rates in this category indicate students' perseverance in completing a degree. Poor performers prior to switching take longer to graduate and are less likely to graduate. Switching motivated by poor performance can lead to failure to complete the degree if students lose motivation to work hard after switching and fail to perform well enough in their new field of study to graduate.

In Panels $\mathrm{B}$ and $\mathrm{C}$ of Table 8, we report performance before and after switching majors for the above- and below-median switchers as defined in Panel A. TermGPAis provided for terms $(t-1), t$, and $(t+1)$ relative to a given switch term $t$. The results in Panel B indicate that above-median switchers do not improve performance significantly after switching, suggesting that those who switch are more likely to be driven by lack or shift of interests or goals. The slight decline in performance by the non-graduating above-median performers suggests that inefficient switching leads to unfavorable outcomes. The results in Panel $\mathrm{C}$ show that belowmedian switchers improve their performance significantly after switching, and those who continue to maintain the trajectory of improved performance are more likely to graduate. These findings support our prediction in Hypothesis 3 that while switching related to poor performance may increase graduation likelihood, a successful outcome requires continuing effort to improve performance. 


\section{Table 8: Comparison between Students with Above- and Below-Median GPA before Switching}

Panel A reports graduation outcome for above and below median performers. Panel B and C report mean values of term GPA for Above- and Below-median switchers respectively, who switch majors in term $t$. TermGPAis provided for terms $(t-1), t$, and $(t+1)$ relative to a given switch term $t$.

Panel A: Graduation outcome for above and below median performers

\begin{tabular}{|c|c|c|c|}
\hline & Above-median switchers & Below-median switchers & $p$-value for Difference \\
\hline Percentage of students & 38.79 & 61.21 & \\
\hline Graduates (\%) & 83.89 & 68.31 & 0.00 \\
\hline Number of years to graduate & 4.43 & 5.32 & 0.00 \\
\hline Number of terms to declare graduating major & 5.28 & 6.67 & 0.00 \\
\hline $\begin{array}{l}\text { Number of terms to complete graduation } \\
\text { after declaring the graduating major }\end{array}$ & 3.58 & 3.97 & 0.23 \\
\hline
\end{tabular}

\begin{tabular}{|c|c|c|c|c|c|c|}
\hline \multicolumn{7}{|c|}{ Panel B: Above-median switchers: based on performance one term before switching } \\
\hline \multicolumn{4}{|c|}{ Mean } & \multicolumn{3}{|c|}{ p-Value for Difference } \\
\hline & TermGPA $A_{i, t-1}$ & TermGPA $A_{i, t}$ & $\operatorname{TermGPA}_{i, t+1}$ & $\begin{array}{l}(t-1) \\
\text { and } t\end{array}$ & $\begin{array}{l}t \text { and } \\
(t+1)\end{array}$ & $\begin{array}{l}(t-1) \text { and } \\
(t+1)\end{array}$ \\
\hline Graduates and Non-graduates & 3.16 & 3.12 & 3.10 & 0.41 & 0.68 & 0.22 \\
\hline Graduates & 3.21 & 3.15 & 3.16 & 0.27 & 0.91 & 0.33 \\
\hline Non-graduates & 2.98 & 3.00 & 2.81 & 0.89 & 0.30 & 0.36 \\
\hline \multicolumn{7}{|c|}{ Panel C: Below-median switchers: based on performance one term before switching } \\
\hline \multicolumn{4}{|c|}{ Mean } & \multicolumn{3}{|c|}{ p-Value for Difference } \\
\hline & TermGPA $A_{i, t-1}$ & TermGPA $A_{i, t}$ & TermGPA $A_{i, t+1}$ & $\begin{array}{l}(t-1) \\
\text { and } t\end{array}$ & $\begin{array}{l}t \text { and } \\
(t+1)\end{array}$ & $\begin{array}{l}(t-1) \text { and } \\
(t+1)\end{array}$ \\
\hline Graduates and Non-graduates & 2.44 & 2.67 & 2.67 & 0.00 & 0.98 & 0.00 \\
\hline Graduates & 2.64 & 2.85 & 2.86 & 0.00 & 0.94 & 0.00 \\
\hline Non-graduates & 1.94 & 2.19 & 2.13 & $0 . .06$ & 0.67 & 0.17 \\
\hline
\end{tabular}


We analyze performance before and after switching in a panel regression setting in Table 9. The analysis includes only students who switch majors. The dependent variable is TermGPA and the panel regression includes performance for terms $(t-1), t$, and $(t+1)$ relative to a given switch term $t$. Above- (below-) median switchers include students with performance above (below) the median GPA for the declared major one term before the switch. Models 1 and 2 include all students who switch majors, models 3 and 4 include Below-Median Switchers, and models 5 and 6 include Above-Median Switchers. Multiple switchers are excluded from the analysis; however, including them provides similar effects. The independent variable One term prior to (after) switch, is an indicator variable equal to 1 if the term is one term before (after) the term in which a student switches, and 0 otherwise. Graduate (Non-graduate) takes a value equal to 1 if the student in the 2006 cohort graduates (does not graduate) by fall 2015, and 0 otherwise.

The coefficients of independent variables One term prior to (after) switch captures the performance of students one term before (after) changing majors relative to the term in which the change takes place. The interaction of One term prior to (after) switch with Graduate (Nongraduate) captures the performance one term before (after) a switch relative to the term in which the switch takes place for students who graduate (do not graduate). To address any concern that the results might be driven by observable or unobservable student characteristics we add student fixed effects in all models. In addition, all models include control variables similar to Table 3 (excluding Number of times change major) and include a student ethnicity dummy.

Table 9: Students’ Performance Before and After Switching Majors

The table presents an analysis of the performance of students one term before and after switching majors.

\begin{tabular}{|c|c|c|c|c|c|c|}
\hline \multicolumn{7}{|l|}{ Dependent variable: Term GPA } \\
\hline \multirow[b]{2}{*}{ VARIABLES } & \multicolumn{2}{|c|}{ All Switchers } & \multicolumn{2}{|c|}{$\begin{array}{l}\text { Below-Median } \\
\text { Switchers }\end{array}$} & \multicolumn{2}{|c|}{$\begin{array}{l}\text { Above-Median } \\
\text { Switchers }\end{array}$} \\
\hline & $(1)$ & $(2)$ & (3) & (4) & (5) & $(6)$ \\
\hline One term prior to switch & $\begin{array}{l}-0.152 * * \\
(-2.30)\end{array}$ & & $\begin{array}{l}-0.315^{* *} \\
(-2.61)\end{array}$ & & $\begin{array}{l}0.157 * * * \\
(3.93)\end{array}$ & \\
\hline One term after switch & $\begin{array}{l}-0.001 \\
(-0.02)\end{array}$ & & $\begin{array}{l}-0.005 \\
(-0.06)\end{array}$ & & $\begin{array}{l}0.008 \\
(0.26)\end{array}$ & \\
\hline One term prior to switch* & & & & & & \\
\hline Graduates & & $\begin{array}{l}-0.152^{* * * *} \\
(-3.47)\end{array}$ & & $\begin{array}{l}-0.349 * * * \\
(-4.64)\end{array}$ & & $\begin{array}{l}0.155^{* * *} \\
(3.55)\end{array}$ \\
\hline One term after switch*Graduates & & $\begin{array}{l}0.021 \\
(0.59)\end{array}$ & & $\begin{array}{l}0.016 \\
(0.32)\end{array}$ & & $\begin{array}{l}0.030 \\
(0.86)\end{array}$ \\
\hline One term prior to switch* & & & & & & \\
\hline Non-Graduates & & $\begin{array}{l}-0.153 \\
(-0.51)\end{array}$ & & $\begin{array}{l}-0.249 \\
(-0.65)\end{array}$ & & $\begin{array}{l}0.168^{*} \\
(2.30)\end{array}$ \\
\hline One term after switch* & & & & & & \\
\hline Non-Graduates & & $\begin{array}{l}-0.066 \\
(-0.45)\end{array}$ & & $\begin{array}{l}-0.060 \\
(-0.29)\end{array}$ & & $\begin{array}{l}-0.105 \\
(-1.34)\end{array}$ \\
\hline Constant & $\begin{array}{l}3.920 * * * \\
(123.64)\end{array}$ & $\begin{array}{l}5.669 * * * \\
(144.56)\end{array}$ & $\begin{array}{l}-0.525^{* * *} \\
(-6.17)\end{array}$ & $\begin{array}{l}-5.335 * * * \\
(-9.28)\end{array}$ & $\begin{array}{l}0.202 * * * \\
(13.47)\end{array}$ & $\begin{array}{l}0.838 * * * \\
(15.08)\end{array}$ \\
\hline
\end{tabular}

Journal of the Scholarship of Teaching and Learning, Vol. 18, No. 3, September 2018. josotl.indiana.edu 


\begin{tabular}{lllllll} 
Controls & Yes & Yes & Yes & Yes & Yes & Yes \\
Student F. E. & Yes & Yes & Yes & Yes & Yes & Yes \\
Ethnicity F. E. & Yes & Yes & Yes & Yes & Yes & Yes \\
Observations & 1,341 & 1,341 & 875 & 875 & 464 & 464 \\
Adjusted R-squared & 0.448 & 0.447 & 0.285 & 0.285 & 0.415 & 0.414 \\
\hline
\end{tabular}

Note: Values of $t$-statistics are reported in parentheses and are based on robust standard errors clustered at the students' ethnicity level. ***, **, and * indicate significance at the $1 \%, 5 \%$, and $10 \%$ levels, respectively.

The results in Table 9 reconfirm our univariate findings that lack of performance can trigger switching; however, a successful outcome requires a trajectory of improved performance. Results for Below-Median Switchers (model 4) suggest that switching related to poor academic performance leads to degree completion for students who improve their performance after switching. For below-median switchers who fail to graduate, there is no significant improvement in performance after switching. Above-median switchers (models 5 and 6) do not experience improvement in performance after switching; rather both graduates and non-graduates show a decline in performance after switching. This suggests that switching by high performers could be related to shifting interests or goals and sometimes leads to inefficient switching and unsuccessful outcomes. Hence the results support our prediction in Hypothesis 3 that switching to a suitable major because of poor prior performance can lead to better outcomes; however, successful completion of a degree requires improving academic performance.

\section{Conclusion}

Our results suggest that colleges and universities should allocate additional resources to helping students explore which major may be the best fit for them. Once students have chosen a major, colleges and universities should continue to encourage students to reflect on the quality of their initial decision while keeping the option open to switch majors. The typical advice to "stick it out and finish what you've started" may not be optimal. Time spent in an existing major is a sunk cost. The decision to change majors or remain in the current major should be based on marginal costs. Our results indicate that the marginal costs of remaining in a major may be higher than previously realized.

Universities and colleges should try to identify students who change majors because of poor performance or because their interests shift and guide those students toward a path that leads to graduation. Students who perform poorly may do so because they have lost interest in their chosen major field. In that case, the reason for changing majors might not be readily detectable. If switching is mainly due to students' loss of interest, the college should try to identify why those students lost interest. If the switch is driven by poor performance, the college can try to identify what special support students might need in order to succeed before changing majors, offer guidance in course selection, and provide motivational counseling. Relevant questions to ask are: whether students have exerted sufficient effort; whether students were guided into the right set of courses along the way; what fundamental or prerequisite courses students need in order to best succeed in the chosen major; and which course(s) in any given major trigger switching behavior, either because of their difficulty level or a lack of available support. Identifying ways to improve effective learning and student interest in a field, providing necessary academic support services through counseling and supplemental instruction, and identifying a major that matches the skills and interests of students are a few avenues to explore 
in order to address students' concerns related to finding a suitable major, sticking with it, or changing it as deemed necessary.

\section{Appendix}

\section{Appendix 1. Table A.1: Variable Definitions}

Variables

Attributes Related to Graduation

Graduate

Graduate within 4 years

Graduate within 5 years

Graduate within 6 years

Number of undeclared major terms

Number of times change major

Terms to declare graduating major

\% Students undeclared major

\% Student change major
Definition

Equal to 1 if the student in the 2006 cohort graduates by fall 2015, and 0 otherwise.

Equal to 1 if the student graduates within 4 years, and 0 otherwise

Equal to 1 if the student graduates within 5 years, and 0 otherwise.

Equal to 1 if the student graduates within 6 years, and 0 otherwise.

Number of terms before a student declares a major Number of times a student changes majors.

Number of terms a student takes to declare the graduating major. We match term major with the graduating major to identify the term in which the student chooses the graduating major. The number of terms until the match is found is the number of terms it takes to declare a graduating major.

Percentage of students who declare a term major after the first term.

Percentage of students who change majors in the reported terms.

Performance Measures

SAT score

Term GPA

Cumulative GPA

Graduating GPA

Major GPA above median (\%)

Above-median GPA
SAT score earned by the student

Average term GPA for the student

Average GPA of student for the reporting terms

Final GPA upon graduation

Percentage of students above the median GPA in the major in a given term

Equal to 1 if student GPA is above the median GPA in the major declared by the student for the given term

Financial Aid

Hope present

Pell grant present

Percentage of terms student has HOPE scholarship available.

Percentage of terms student has Pell grant available.

Journal of the Scholarship of Teaching and Learning, Vol. 18, No. 3, September 2018. 


\begin{tabular}{|c|c|}
\hline Female & Equal to 1 if the student is female, and 0 otherwise. \\
\hline Citizen & $\begin{array}{l}\text { Equal to } 1 \text { if the student is a citizen of the U.S., and } 0 \\
\text { otherwise. }\end{array}$ \\
\hline$\%$ resident alien & Percentage of students with resident status. \\
\hline$\%$ non-resident alien & Percentage of students with non-resident alien status. \\
\hline \% White & $\begin{array}{l}\text { Percentage of students in the sample whose ethnicity is } \\
\text { white. }\end{array}$ \\
\hline$\%$ Black & $\begin{array}{l}\text { Percentage of students in the sample whose ethnicity is } \\
\text { black. }\end{array}$ \\
\hline$\%$ Asian & $\begin{array}{l}\text { Percentage of students in the sample whose ethnicity is } \\
\text { Asian. }\end{array}$ \\
\hline \% Hispanic & $\begin{array}{l}\text { Percentage of students in the sample whose ethnicity is } \\
\text { Hispanic. }\end{array}$ \\
\hline \% Other ethnicity & $\begin{array}{l}\text { Percentage of students in the sample whose ethnicity is } \\
\text { undeclared or who belong to groups other than white, } \\
\text { black, Asian, or Hispanic. }\end{array}$ \\
\hline
\end{tabular}

\section{References}

ACT, (2010). What Works in Student Retention: Fourth National Survey. http://www.act.org/content/dam/act/unsecured/documents/Retention-AllInstitutions.pdf

Adelman, C. (1999). Answers in the tool box: academic intensity, attendance patterns, and bachelor's degree attainment. Washington, DC: U.S. Department of Education.

Angrist, J. D., Lang, D., and Oreopoulos, P. (2009). Incentives and services for college achievement: Evidence from a randomized trial. American Economic Journal: Applied Economics, 1, 1-28.

Angrist, J. D. and Lavy, V. (2009). The effects of high stakes high school achievement awards: Evidence from a randomized trial. American Economic Review, 99(4), 1384-1414.

Astin, A. W. (1993). What matters in college: Four critical years revisited. San Francisco: Jossey Bass.

Braxton, J. M. (2000). Reworking the student departure puzzle. Nashville, TN: Vanderbilt University Press.

Braxton, J. M. and McClendon, S. A. (2002). The fostering of student integration and retention through institutional practice. Journal of College Student Retention: Research \& Practice, 3(1), 57-71.

Bremer, C. D., Center, B. A., Opsal, C. L., Medhanie, A., Jang, Y. J., and Geise, A. C. (2013). Outcome trajectories of development students in community colleges. Community College Review, 41(2), 154-175. 
Cabrera, A. F., Nora, A., and Castaneda, M. B. (1993). College persistence: Structural equations modeling test of an integrated model of student retention. Journal of Higher Education, 64(2), 123-139.

Cornwell, C., Mustard, D. B., and Sridhar, D. J. (2006). The enrollment effects of merit-based financial aid: Evidence from Georgia’s HOPE program. Journal of Labor Economics, 24(4), 761-786.

Deming, D. and Dynarski, S. (2009). Into college, out of poverty? Policies to increase the postsecondary attainment of the poor. NBER Working Paper Series, No. 15387.

Dynarski, S. (2002). The consequences of merit aid. NBER Working Paper Series, No. 9400. Dynarski, S. (2005). Building the stock of college-educated labor. NBER Working Paper Series, No. 11604.

Davidson, W B., Beck, H. P., and Milligan, M. (2009). The college persistence questionnaire: Development and validation of an instrument that predicts student attrition. Journal of College Student Development, 50(4), 373-390.

Eckstein, Z. and Wolpin, K. I. (1999). Why youths drop out of high school: The impact of preferences, opportunities, and abilities. Econometrica, 67(6), 1295-1340.

Engle, J. and Tinto, V. (2008). Moving beyond access: College success for low-income, firstgeneration students. The Pell Institution, for the Study of Opportunity in Higher Education. http://files.eric.ed.gov/fulltext/ED504448.pdf

Engstrom, C. and Tinto, V. (2008). Learning better together: The impact of learning communities on the persistence of low-income students. Opportunity Matters, 1, 5-21.

Fike, D. S. and Fike, R. (2008). Predictor of first-year student retention in the community college. Community College Review, 36(2), 68-88.

Hirschy, A. S., Bremer, C. D., and Castellano, M. (2011). Career and technical education (CTE) student success in community colleges: A conceptual model. Community College Review, 39, 296-318.

Hotz, V. J., Xu, L., Tienda M., and Ahituv, A. (2002). Are there returns to the wages of young men from working while in school? The Review of Economics and Statistics, 84(2), 221 - 236.

Ishitani, T. T. and DesJardins, S. L. (2002). A longitudinal investigation of dropout from college in the United States. Journal of College Student Retention: Research, Theory \& Practice, 4(2), 173-201.

Kennedy, P. W., Sheckley, B. G., and Kehrhahn, M. T. (2000). The dynamic nature of student persistence: Influence of interactions between student attachment, academic adaptation, and 
social adaptation. Paper presented at the Annual Meeting of the Association of Institutional Research, Cincinnati, $\mathrm{OH}$.

Kern, C. W., Fagley, N. S., and Miller, P. M. (1998). Correlates of college retention and GPA: Learning and study strategies, testwiseness, attitudes, and ACT. Journal of College Counseling, 98, 26-34.

Mangold, W. D., Bean, L. G., Adams, D. J., Schwab, W. A., and Lynch, S. M. (2003). Who goes who stays: An assessment of the effect of a freshman mentoring and unit registration program on college persistence. Journal of College Student Retention, Theory \& Practice, 4(2), 95-122.

Nandeshwar, A., Menzies, T., and Nelson, A. (2011). Learning patterns of university student retention. Expert Systems with Applications: An International Journal, 38(12), 14984-14996.

O’Brien, C. and Shedd, J. (2001). Getting through college: Voices of low-income and minority students in New England. The New England student success study. Washington, DC: The Institute of Higher Education Policy. https://www.nmefoundation.org/getmedia/a434a86c-b690-430a-a2cc-e6bb294fb74a/gettingthrough-college?ext=.pdf

Pascarella, E. T. and Terenzini, P. T. (1991). How college affects students: Findings and insight from twenty years of research. San Francisco: Jossey-Bass.

Peltier, G. L., Laden, R., and Matranga, M. (1999). Student persistence in college: A review of research. Journal of College Retention, 1, 357-376.

Seligman, J., Milford R., O’Looney J., and Ledbetter, J. (2004). HOPE scholarship joint study commission report. Athens, GA: Carl Vinson Institute of Government. http://www.cviog.uga.edu/free-downloads/hope-joint-study-commission-report.pdf

Stinebrickner, R. and Stinebrickner, T. R. (2004). Time-use and college outcomes. Journal of Econometrics, 121(1-2), 243-269.

Stinebrickner, R., and Stinebrickner, T. R. (2008). The causal effect of studying on academic performance. The B.E. Journal of Economic Analysis \& Policy, 8(1), 1-55.

Tinto, V. (1975). Dropout from higher education: A theoretical synthesis of recent research. Review of Educational Research, 45(1), 89-125.

Tinto, V. (1997). Classrooms as communities: Exploring the educational character of student persistence. Journal of Higher Education, 68(6), 599-623.

Tinto,V. (2006). Research and practice of student retention: What next? Journal of College Student Retention, 8(1), 1-19 
Tyler, J. H. (2003). Using state child labor laws to identify the effect of school-year work on high school achievement. Journal of Labor Economics, 21(4), 381-408.

Wyckoff, S. C. (1998). Retention theories in higher education: Implications for institutional practice. Recruitment and Retention in Higher Education, 12(2), 2-7. 